\title{
The Politics of Talk on German Free Radio Stations
}

\section{Jan Pinseler \\ Institute of Communication Studies and Media Culture \\ Lüneburg University}

Keywords: $\quad$ radical media, conversation analysis, community radio, free radio

\begin{abstract}
Today there are a wide range of non-commercial radio stations in Germany. Though mostly treated similarly by broadcasting authorities there are major differences in how these stations are thought of and run. This paper argues that for community radios to be radical media they have to develop a way of empowering people to use radio for promoting their issues, especially helping those who are normally not heard. This goes far beyond the training for media literacy most German broadcasting regulators encourage. Drawing on a conversation analysis case study of current affairs programmes on a German Free Radio station, it is pointed out that these shows incorporate both forms of talk that encourage political participation and thereby successfully empower people to take part in political discourse and forms of talk that simply imitate commercial and public service broadcasting stations, thereby applying power structures inherent in these organisations to community radio.
\end{abstract}

\section{Introduction}

Free Radio is a special form of community broadcasting developed by the social movements of the 1960s with roots going back to the 1930s and rediscovered in the early 1990s. It is different from other forms of broadcasting, public service as well as commercial radio and even from other forms of non-commercial media. This paper explores exactly what this difference is made of. It argues that alternative radio become radical media if they not only use radio to transmit content alternative to public service and commercial media but also revolutionise the relationship between producers and listeners.

Today there is a wide range of community radio stations in Germany. While some of them call themselves "free radio" others prefer the term "citizens' radio" or are students' or university stations. With the introduction of new broadcasting acts in several German states in the late 1990s the new term of "non-commercial local radio broadcasting" was coined to subsume these different forms under one common label. But this label obscures basic differences between these forms.

Westminster Papers in Communication and Culture (C) 2008 (University of Westminster, London), Vol. 5(1): 67-85. ISSN 1744-6708 (Print); 1744-6716 (Online) 
While one could argue that it gets increasingly harder to draw the lines between free radio stations and other forms of community or non-commercial radio stations, I will point out that these differences are not only differences of labelling but - more importantly - differences of political practice. Using a case study of a German free radio station I will outline these practices and, deducing from that and theoretical deliberations on free radio, describe the potential of free radio. Finally I will describe prospects, problems and pitfalls of free radios in Germany today and argue, that certain practices may help and other practices might interfere with upholding free radios as radical media important for today's ongoing social debates.

Radical media is a term used by Downing $(1984 ; 2001)$ to describe those media organisations that try to counter hegemonic productions of meaning. Other terms used are community media, alternative media, citizens' media or participatory media. ${ }^{1}$ While there are several common characteristics of media organisations described by these terms, "radical media" points out an attempt to change society, an attempt that is blurred - sometimes on purpose - by other terms. Therefore, I will describe free radio as a specific form of radical media. While being politically radical was taken for granted when the first free radio stations were founded, the institutionalisation of non-commercial radio in Germany brought about a change that might lead to a taming of free radio, eventually depriving it of its radical social impact. To describe this change we have to start by looking at the history of free radio in Germany.

\section{Community Radio in Germany}

\section{Historical Perspective}

The History of German Free Radio stations is a divided one. In West Germany the first free radio stations appeared in the mid 1970s. In East Germany, they were founded in the aftermath of the 1989 revolution. Not until the second half of the 1990s, free radio stations got licensed and could finally go on air permanently. It was no coincidence that the first attempts to found free radio stations in West Germany occurred in the 1970s. This is due to two reasons: The rising of the West German social movement and the discussion about the introduction of commercial broadcasting. In addition, free radio pioneers were inspired by the German workers' radio movement of the 1920s and looked across the borders at the radios libres in France and Italy. ${ }^{2}$

Beginning in 1968 new social movements had gained strength, most notably the movement against nuclear power plants, the squatter movement and the peace movement. They felt that their issues were ignored, distorted or misrepresented by public broadcasting. Hence, demands for what was called "unmediated 
communication", i.e. for media operated by these groups themselves, increased (Faecke/Haag, 1977; Network Medien-Cooperative, 1983). This not only resulted in demands for electronic media run by these groups but also in the development of an alternative media practice. Most notably, this practice was characterised by establishing structures of media production that were self-determined and selfcontrolled. While a few years earlier the students' movement had tried to change existing media, now alternative local magazines, video production groups and media workshops were founded. In contrast to the allegedly objective reporting of mainstream media corporations they aimed at a form of reporting that was involved in what it talked about and based on being personally affected. In addition, they tried to put the concept of a counter public sphere into practice, i.e. establishing an alternative public sphere organised by the new social movements themselves (e.g. Stamm, 1991, 370).

As an example of how this could be done the first Italian radios libres, broadcasting since 1975, had made a great impression on West German left movements (Ruoff, 1978). These broadcasting stations were free insofar as they were not operated by RAI, the Italian state broadcaster. They were tolerated and eventually legalised by the constitutional court in 1976, which decided that the RAI monopoly was unconstitutional (e.g. Lewis/Booth, 1989). Most of these local radio stations were commercial ones, but, according to Eco and Grieco (1978) twenty to thirty percent were based on a community or described themselves as political stations. They opened up radio to those who until then did not have the opportunity to use it as a means of communication. Especially, Radio Alice in Bologna and Radio Popolare Milano did not only fill their programmes with different contents but fundamentally changed the way radio was organised and produced. According to the Italian Federation of Democratic Radio Stations they aimed at (1) a collective production of programmes and self-organisation of the radio station, (2) free access for people personally affected by something to the programme and (3) unmediated forms of communication (FRED, 1977). Thereby, these radio stations organised listeners as suppliers.

In the mid 1970s first attempts to establish free radios in West Germany were made which transmitted their programmes illegally. E.g., in 1975 a pirate radio Piratensender Unfreies Westberlin started to transmit "corrections" of "suppressed and falsified news". Stations in Heidelberg, Freiburg and Münster followed (Network Medien-Cooperative, 1983). These political pirate stations aimed at transforming radio from a distribution apparatus into a communication apparatus and thus make it a mouthpiece for those who normally do not have a public voice (Busch, 1981).

When commercial broadcasting was finally introduced to West Germany in 1984, the new broadcasting laws did not provide for community radio. Exhausted by years of organising illegal radio transmissions and being persecuted by state 
authorities vigorously enforcing the law, one free radio station after the other capitulated and vanished. The idea of free radio was pronounced dead by most (e.g. Vogel, 1991). After a long battle, only Radio Dreyeckland, based in Freiburg near the French and Swiss borders, got a license for a local radio station in 1987 after having hidden their transmitters for illegal programmes on all sides of the border for years.

From the outside the idea of free radio seemed to be dead in Germany. But as free radio activists met in 1992 for the first time in years it became clear that the movement was alive and well. In West Germany a new generation of activists had emerged in result of renewed criticism of public service and commercial broadcasting. Around the same time new groups had emerged in East Germany following the upheaval of 1989. The latter had used the transition period between the East German uprising in October 1989 and German unification, when existing laws prohibiting non-state radio stations were not enforced, for transmitting their programmes. Initiatives for free radio stations were founded in East Berlin, Erfurt, Dresden and Chemnitz. Due to this double tracked development, in the early 1990s a new German free radio movement had evolved. While the aims of these radio stations were different in detail they all aimed at founding non-commercial and democratic radio stations which critically discussed current social conditions and were open especially to those who normally do not have a voice in media.

With the advent of commercial broadcasting in West Germany in 1984, instead of legalising existing free radio stations, public access channels ("Offene Kanäle") were founded in several cities serving as a fig leaf for privatised broadcasting. Everybody could come to these local cable channels and produce programmes that were transmitted based on a first come first served principle. But instead of political arguments most of these programmes consisted of rather poor imitations of private broadcasting embodied by narcissistic entertainers. At the same time free radio was still not getting licensed. That this changed since the mid 1990s and that there are quite a few non-commercial radio stations in Germany today is due to two developments. Now it was finally obvious that allowing commercial broadcasting had caused a commercialisation of both types of broadcasting, not only of commercial stations but also public service ones. This was no surprise as far as commercial broadcasting was concerned. But public service broadcasting also less and less became a medium for public and multifaceted debates on social issues. This opened up a gap community radios could fill.

\section{Potential of Free Radio - Some Theoretical Deliberations}

As a result, in the last ten to fifteen years a large and multifaceted scene of local radio stations has developed in Germany. This consists, on the one hand, of quite a few public access channels and, on the other hand, non-commercial local radio 
stations. While public access channels are - at least in principle - open for everybody and all kinds of programmes, non-commercial radio stations are organised by their users and collectively decide which programmes get on the air. In addition, different non-commercial stations also may have different policies.

The largest identifiable group of non-commercial radio stations consists of those who call themselves free radio stations ("Freie Radios") and constitute the federal association of free radio stations ("Bundesverband Freier Radios, BFR"). These stations see themselves as the successors of 1970 s free radio stations. They are different from public service broadcasters, commercial stations, university and training radio stations because they encourage ordinary people to contribute programmes and to take part in the everyday running of the station. Their organisation therefore aims at being open to outsiders and at having a programme schedule that makes selective listening possible. They aim to encourage collective production of programmes and a public discussion about what will be put on the air. The overall idea of free radio stations is creating a joint production of a coherent product, not individual production of shows. Free radio stations are financed mostly by membership fees and donations and to some degree depending on the federal states - by federal broadcasting authorities. As a matter of principle they do not transmit commercials.

This practice generated a considerable body of theoretical debates on free radio. ${ }^{3}$ In the following I will - very briefly - discuss and summarise these debates. Deducing from them I will outline the potential free radios might have. The Italian experience that was so influential in the early history of free radio in Germany was discussed on a theoretical level but - due to the specific West German situation barely copied. Critical media theories of Brecht (1975, orig. 1932) and Benjamin (1978, orig. 1934), Enzensberger (1970) and Negt/Kluge (1993, orig. 1972) became a focus point for the everyday practice of West German free radio in the 1970s instead. What today is knows as Brecht's "radio theory" is mostly based on a speech on the role of radio he gave in 1932 and in which he famously demands to 'change this apparatus over from distribution to communication' by 'organizing its listeners as suppliers' (Brecht, 1993, 15). Ignoring the pedagogical impetus of Brecht's speech, this quote became a stock phrase for German free radio stations, describing the vision of what these radios aimed to achieve. While Brecht discussed the role of radio as an apparatus, Benjamin (1978) looked at the role of the author in this apparatus. He points out, that change can only be achieved by socialisation of the means of production and not by simply providing different content. According to Benjamin, the author cannot only work on his text but also has to attempt to change the means of production. Enzensberger (1970) refers to Brecht's and Benjamin's considerations, but falls behind their insights. While Benjamin demands of the author to involve listeners as collaborators, Enzensberger demands of the author to enlighten the recipient. According to 
Enzensberger, only after a victory of the masses the author could vanish. Therefore, while Brecht and Benjamin pointed out a way to change the medium (Brecht) and the author (Benjamin), Enzensberger wanted to change the media by radical intellectuals infiltrating broadcasting institutions. But all these theories are characterised by proximity to existing media. They did not try to conceptualise new forms of media use but rather to reform existing media institutions and use these institutions for emancipatory uses.

While the fundamental principle of West German free radio stations in the 1970s and 1980s was to establish a counter public sphere (Weichler, 1987; Stamm, 1991), this concept was increasingly criticised in the 1990s and increasingly less relevant for the everyday work of free radio stations. The idea of a counter public sphere developed in the early 1970s when the than new social movements felt that their intentions were mostly distorted or ignored on public radio and television and in newspapers. Therefore, these movements started to develop their own media. Doing this, they aimed at building a counter public sphere that corrected and complemented the mainstream media. Reasons for criticising this concept of a counter public sphere were manifold. It was argued that it followed the operating mode of media in a capitalist society and simply mirrored its content. Media that tried to establish a counter public sphere aimed at correcting and supplementing the existing media instead of self-confidently producing what they deemed important without constantly reacting to the output of established media corporations, argued, for instance, Agentur Bilwet (1993). Also, the model of a counter public sphere was seen as based on a simple hypodermic needle model of media communication and therefore bearing some problems if used as a manual on how to produce programmes on free radio stations. Language should rather be seen as a contested resource of power. Therefore the conditions of speaking and listening had to be changed (Diefenbach, 1998; Stötzler, 1998; Wenzel, 1998).

To sum up these theoretical considerations on the practice of free radio stations, based on current debates one can point out three different areas in which a radical broadcasting practice might be possible. Firstly, free radio helps disenchanting radio broadcasting. By demonstrating that everyone is able to produce radio programmes, that everyone is an expert of everyday life, it removes the aura of the omniscient medium that is always right. In addition, free radio demonstrates how radio is produced and thereby exposes its techniques, including techniques of manipulation, e.g. how sound bites can be taken out of context and rearranged to become a different meaning. Free radio, secondly, is able to hand the microphone to actual participants and to initiate debates between producers and listeners. Events are showcased by those who are involved in these events, not in a supposedly objective fashion. Doing this, free radio is not a representative of social groups but opens up the airwaves to those who actually take part in these events. As early as 1977 the Italian federation of democratic radio stations had argued: 
It is not important to report that in this or that school the principal's office is seized by students, but it is important that students, who do this, report it and listen to themselves reporting it on the radio. (FRED, 1977, 141)

This also results in the language used on free radio being different from language used on other radio stations. It, thirdly, has to be the language of everyday life. Free radio subsists on an imprecise use of language that allows misunderstandings. It thereby helps to make productive readings of radio texts possible. Thereby, a free radio station does not transmit self-contained messages but impulses for an ongoing social debate. From this it follows that objective reporting is not a reasonable goal for free radio stations. They, on the contrary, have to be subjective. While this cannot mean that they systematically follow an editorial stance, it makes room for a multitude of individual standpoints depending on who is actually speaking. This subjectivity must not be disguised but has to enable listeners to critically asses what the speaker is talking about.

\section{Talking on Free Radio Stations - A Case Study}

\section{Conversation Analysis and Talking on the Radio}

If there is a potential free radio might have it is of interest to analyse to what extent this potential is actually realised. In a case study I have examined current affairs programmes on the Dresden based free radio station coloRadio using conversation analysis. This method can be used to analyse the organisation of talk rather than the topics that are talked about. By doing so, one can assess whether free radio stations are really different in organising a specific relationship between listeners and producers. First, I have looked at a weekly current affairs programme in December 1998 and April and May 1999. In addition, I have analysed several editorial meetings during the same period of time. Secondly, I re-examined the same programme - now transmitted every Monday through Friday - for one week in September 2007, the results of which did not contradict earlier findings. All the programmes were taped and subsequently transcribed to make them available for detailed analysis. Examining the structure of talk occurring in these programmes especially by contrasting it to findings of research on news interviews (see below) , it was described which methods participants in these talks used to create the specific section of social reality that free radio constitutes. Uncovering this everyday construction of social order conclusions can be drawn concerning the possibilities and limits of what free radio can achieve and, more specifically, how the relationship between listeners and producers is organised - a vital point of what could make free radio radical media, as is argued above.

Conversation analysis has been developed by Harvey Sacks and Emanuel Schegloff in the 1960s for examining everyday talk (Sacks/Schegloff/Jefferson, 1974). It 
aims at reconstructing how reality is produced in ordinary conversations. Conversation analysis tries to discover basic structures and rules of social interaction and to demonstrate how this order manifests itself in talk-in-interaction (Heritage/Clayman/Zimmerman, 1988; Heritage/Greatbatch, 1991; Psathas, 1995). Techniques to conduct a conversation are basic techniques of interaction. Therefore, they are the basis for institutionalised forms of interaction which can be described by showing how they differ from ordinary everyday conversations (Heritage/Greatbatch, 1991). Quite a few studies have utilised conversation analysis for researching news interviews. These have been able to show how these differ from everyday conversations (e.g. Heritage, 1985; Heritage/Clayman/Zimmerman, 1988; Heritage/Greatbatch, 1991): News interviews only allow questions and answers, determining in advance that the interviewer asks questions and the interviewee answers them. Interviewers might utter preliminary statements that lead to a question or substantiate a question, but this always leads to some form of question being asked. Therefore interviewer and interviewee jointly produce the interactive form called news interview. In contrast to ordinary conversations participants in news interviews avoid continuers, those small utterance like "yes" or "hm", which in ordinary conversation signal attention. Interviewers systematically avoid to take a stand on anything the interviewee says. Individual turns in news interviews are often longer than those in ordinary talk. They consist of several turn-constructing units which follow each other without interruption. Interviewers expect this from interviewees. This becomes obvious when interviewees give exceptionally short answers that usually lead to a short silence. In news interviews the right to select the next speaker is distributed asymmetrically. Interviewees can neither open or close a conversation nor select themselves as the next speaker (except if several people are interviewed at the same time). Interviewers have the right to choose the topic of the interview and interviewees have to go to great lengths not to break this question-answer-pattern if they wish to avoid answering a question.

Taking these findings on news interviews into account, analysing talk on free radio can reveal the rules followed by those engaging in conversations on free radio programmes. Doing this it can be shown how free radio as a social institution is constructed and which institutional constraints this institution imposes on people acting within it.

\section{Talking Politics - An Example}

There are several different forms of organisations of talk on free radio stations. I will introduce them using one example which contains different systems of organizing talk. ${ }^{4}$ It is taken from a current affairs programme on the Dresden based free radio station coloRadio and was transmitted on 10 December 1998. 
In this broadcast the presenter talks to an elected city councillor about a meeting of the local city council. It is presented here in a translated version. ${ }^{5}$

(01) Transcript: coloRadio-Magazin, 10/12/98

Extract: Stadtrat

Elli-presenter, Vera-on the phone

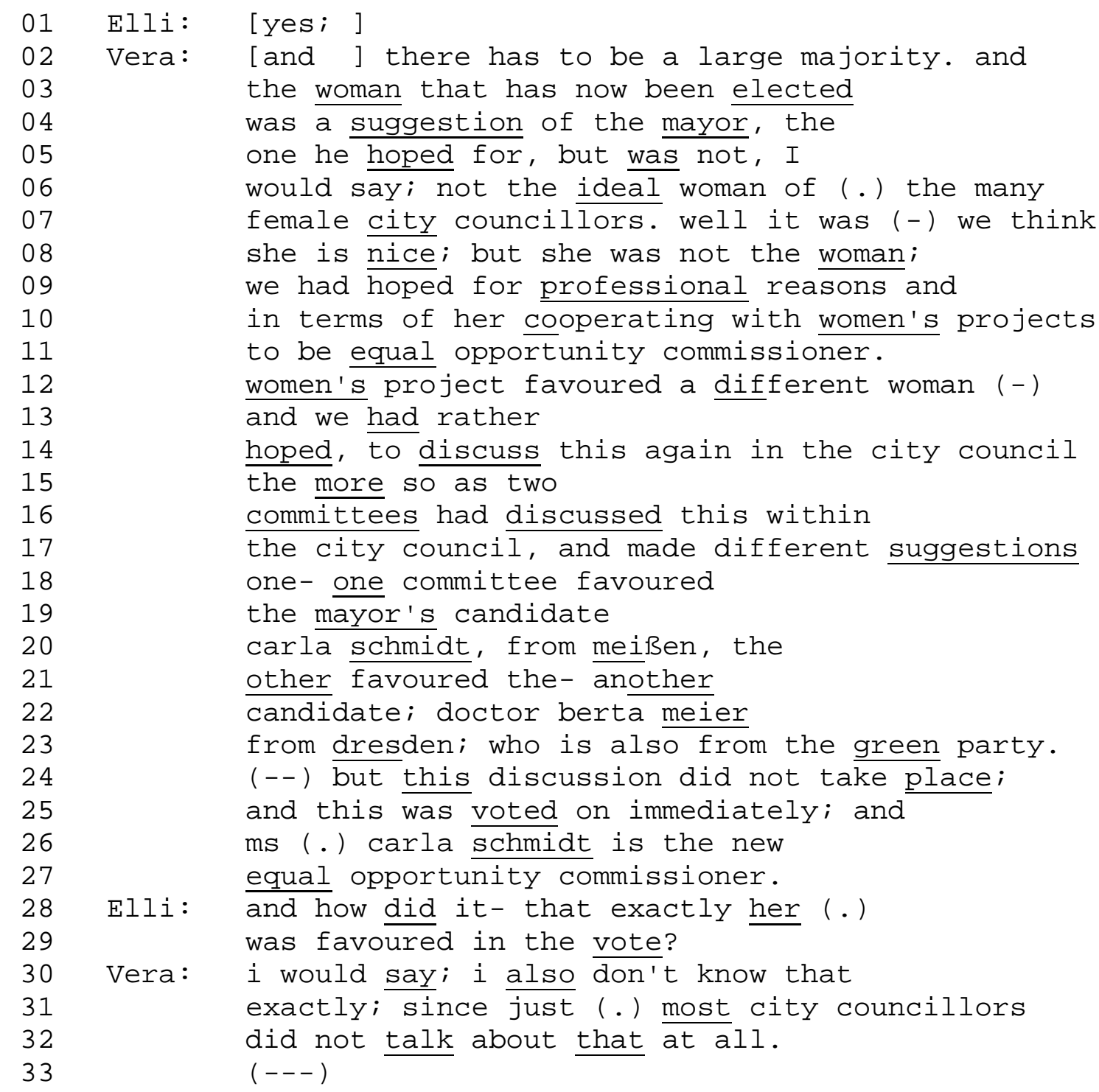

Looking at this extract it is immediately obvious that it starts with a long turn by Vera, the interviewed city councillor. This is typical for the first part of the interview Elli is conducting with Vera. The 'yes' by Elli in line one signals Vera that she is meant to elaborate on what she is talking about. Vera takes advantage of this and goes on for quite a while. In lines one and two the utterances of Elli and Vera overlap, thereby indicating that Vera had not finished talking anyway. Vera's long turn consists of several units that could be turns in themselves. In line 27 the fall in intonation used by Vera and the summary given in lines 25-27 indicate that 
her turn comes to an end. This makes it possible for Elli to select herself as the next speaker. She uses her turn for asking Vera a question she cannot answer. Up to this point this talk looks like a common news interview. Elli produces turns that can be interpreted as questions, Vera produces turns that can be taken as answers and Elli avoids continuers except for the 'yes' in line one. The talk initially goes on in the same way.

(02) Transcript: coloRadio-Magazin, 10/12/98

Extract: Stadtrat (continued)

Elli-presenter, Vera-on the phone

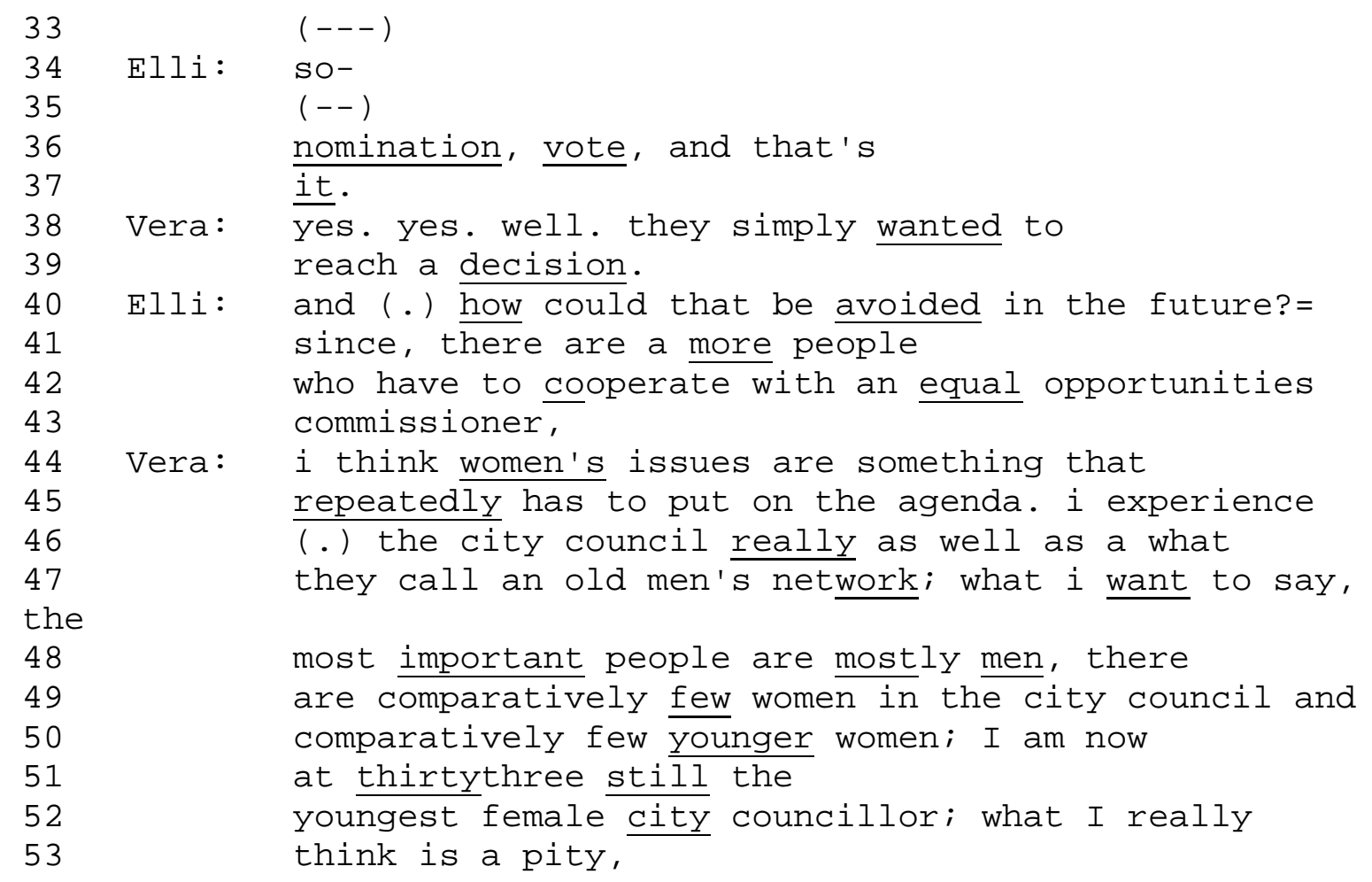

The gaps in lines 33 and 35 reveal that Elli expected a longer answer from Vera. But she had just made the short utterance in lines 30 to 32. Although the presenter obviously does not really know what to say at first - hence the gap in line 35 - she accepts her obligation as an interviewer to speak if no one else does. She resorts to a standard phrase of interviewers by offering the interviewer what Heritage (1985, 106-108) calls a 'cooperative recycle': She sums up Vera's position (lines 36 to 37) and makes it possible for Vera to confirm it (lines 38 to 39). Now Elli asks for consequences this election might have, a question Vera does not really answer. Instead, in lines 44 to 53 she introduces a new topic which the presenter is happy to take up. 
(03) Transcript: coloRadio-Magazin, 10/12/98

Extract: Stadtrat (continued)

Elli-presenter, Vera-on the phone

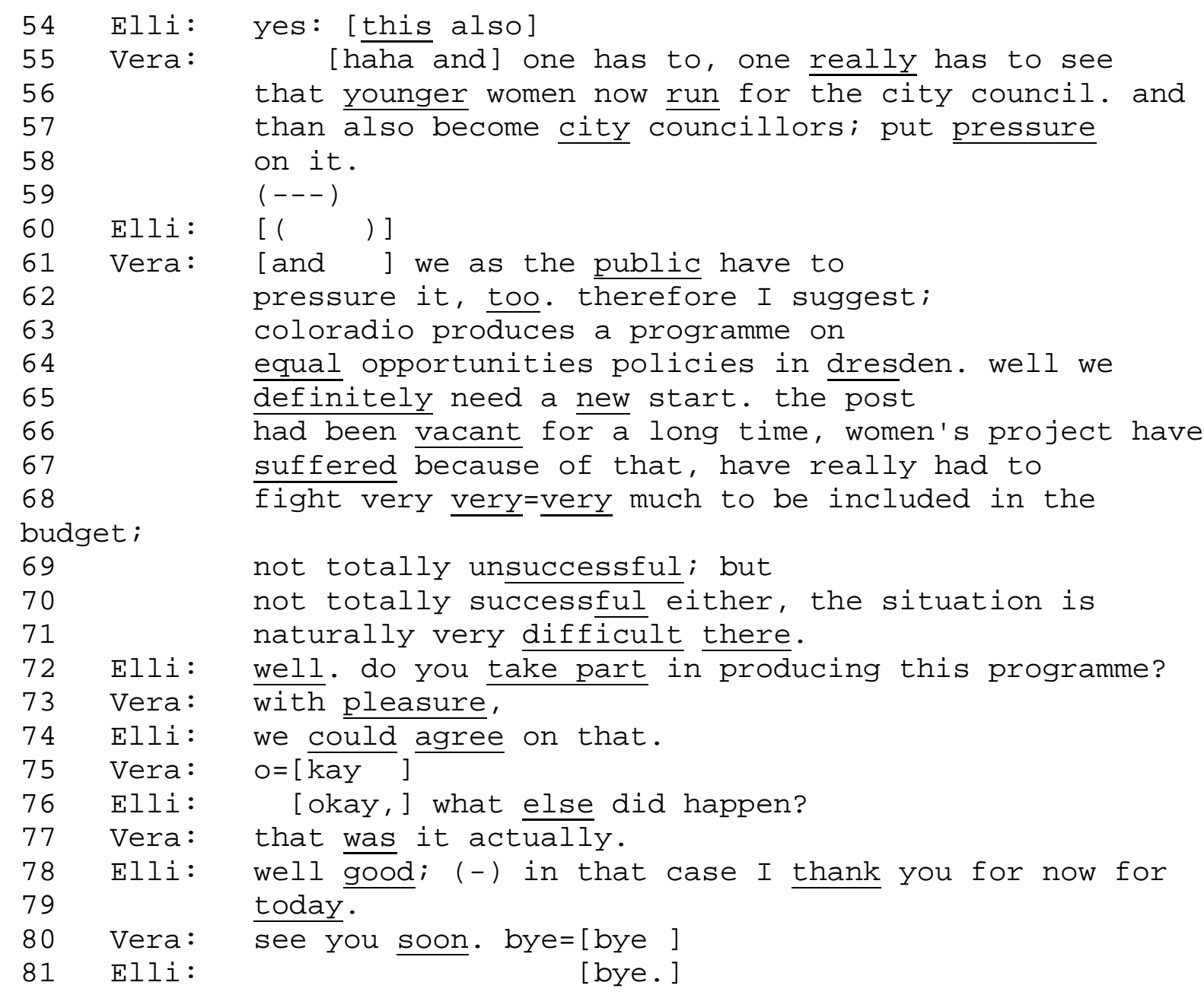

Starting in line 54 Elli deviates from the standard form of a broadcast interview. Not only does she accept the topic Vera introduces into the conversation, she also explicitly agrees with her and thereby compromises her neutral position as an interviewer. Vera uses this to make a political appeal in lines 55 to 58. The gap in line 59 indicates that Vera has finished. But when both start to talk at the same time (lines 60 to 61) after a short overlapping period Elli lets Vera speak again who repeatedly calls for action.

Amazingly, at this point the radio station itself is made an issue on the air by Vera - up to this point an interviewee - suggesting that it should produce a programme on the issue of equal opportunities. The response of the presenter is even more amazing. She asks Vera whether she will take part in producing such a programme (line 72), which she agrees to (line 73). That both react as if this were the most natural thing to say in an interview - the presenter not being irritated in the least by the interviewees suggestion, the interviewee not being surprised by the 
interviewers reaction - shows that on this radio station it is not unusual to publicly talk about how to produce a radio programme and by whom this is done. Obviously, they assume that the audience already knows about this peculiarity.

When Elli and Vera agree on producing the programme the structure of the talk becomes irrevocably different. As far as the content is concerned, they return to the meeting of the city council but the form of talking, especially rules of turn taking, now follow the rules of ordinary everyday conversations. There are short turns, turns overlap and the right to assign turns is distributed more symmetrically. Both participants in this talk have moved from a talk that - as far as the organisation of turn taking is concerned - was similar to news interviews to a talk that follows a system of turn taking similar to everyday conversations. This transition worked smoothly and effortlessly, no obvious break in the conversation can be heard by an ordinary listener. Obviously, the participants are capable of both, conducting a news interview and having ordinary conversations. In their talk on the air they are able to switch between these modes of talk.

\section{Forms of Talk on Free Radio - The Findings}

Loosely following Atkinson (1982) these modes can be called orientation towards formal interaction and orientation towards informal interaction. The orientation towards formal interaction is characterised by an organisation of talk similar to news interviews. It is made up of long individual turns, which consist of multiple units, which in itself could constitute self-contained turns. Participants avoid continuers, the presenter only produces utterances that can be interpreted as questions and ensures that she is perceived as neutral. The interviewee, on the other hand, only produces utterances that can be interpreted as answers. Both, interviewer and interviewee, follow a plan prearranged mainly by the presenter. The interviewer has the right to assign turns and the talk is conducted for an overhearing audience. In addition, the presenter demonstrates her knowledge of the subject matter by implying that she already knows the answer but asks as a substitute for the audience.

In contrast, an orientation towards informal interaction is characterised by those characteristics usually found in ordinary everyday conversations. Individual turns are rather short and there are quite a few overlaps. Participants use continuers to show their interest in the conversation and whether or not they follow what is said. There is a comparably high level of spontaneity and turns are related to each other to a higher degree than in the case of news interviews. While the presenter still has to open and finish the conversation, she is not the only one to assign turns. The conversation itself is not only conducted for the audience but also for the participants, although it is obvious that they are aware of the overhearing audience. 
It is also clear that the presenter is interested in the topic talked about herself and does not always know what answer to expect to a question.

Multiple occurrences of these orientations as well as intermediate stages between these orientations can be found in the programmes I analysed. Obviously, being able to switch effortlessly between formal and informal orientations is a specific characteristic of talk on free radio programmes. This switch even occurs within one and the same conversation. In these talks, the rules of turn taking are predefined to different levels. But even those talks that strongly resemble everyday conversations are never totally undetermined. There is still the presenter's prerogative to initiate and finish the conversation.

As mentioned above, deviations from the everyday organisational system of talk can be ascribed to the institutional context in which conversations occur. Therefore, we can describe which practices of communication are possible on free radio stations. Free radio can be a platform for news interviews. These give people a chance to answer questions on affairs and on beliefs while participants take the interviewer's or the interviewee's position respectively. In addition to news interviews, free radio makes talks possible, in which participants can diverge from these roles. In these cases, interviewers do not need to stick to being neutral and interviewees can take part in setting the agenda of the conversation. The participants are able to switch between these different modes of conversation even within one talk.

In effect, producers on free radio stations have potentially more possibilities to conduct conversations than just news interviews. This means that opposed to public or commercial broadcasting there are not only different topic matters that can be talked about but there is also a way to conduct talk differently from the kind used on professional radio. Conversations being closer to everyday conversations enable those who have no or few experiences in giving news interviews to take part in conversations on free radio programmes and thereby help to organise listeners' participation in the production.

\section{Conclusion}

In the remarks which became famous as his "radio theory" Brecht $(1975,1993)$ describes his vision of radio as a medium that has to be transformed from a 'distribution apparatus' into a 'communication apparatus', one that initiates communication instead of simply addressing it. Brecht goes on to immunise his remarks against critics coming from a realpolitik point of view by adding: 'If you should think this is utopian, then I would ask you to consider why it is utopian' (Brecht, 1975: 130). Every now and then Brecht's vision is said to be realised today. This claim is based on the multiplicity of opportunities available nowadays 
to take part in radio phone-ins, to produce programmes on non-commercial radio stations or to use the internet to say everything one wants to say publicly all along. But the optimism implied in this position ignores the question of who controls commercial and public broadcasting. It also ignores that communication is much more than just coexistence of multiple channels of information. And it ignores that Brecht did not simply demanded that everyone can use a radio station but that the listener has to be organised as a producer. Even non-commercial radio has only been able to live up to these expectations to a limited extend.

Paradoxically both, the commercialisation of private and public service broadcasting and social changes - especially those changes associated with neoliberalism - helped advancing non-commercial broadcasting in Germany. Commercialisation of public service broadcasting had the effect that it less and less fulfilled its so called "basic service", i.e. not only to provide entertainment but also education and information. Especially, public service radio pulled out of local broadcasting and focussed on the federal level, thereby opening up a gap noncommercial station were meant to and some tried to fill. This initiated a debate whether non-commercial radio takes part in providing this basic service (Buchholz, 2005). Doing so would be helpful if applying for more and better radio frequencies and funding. For society in general this function can be fulfilled much cheaper by non-commercial stations than by public service broadcasting since noncommercial stations are run mostly by volunteers doing pro bono work based on self-exploitation.

This is a difficult position for those radio stations who aim at changing society, since their self-administration no longer helps to run a self-organised medium but becomes a possibility to save money and relocating part of basic public services from public service broadcasting to non-commercial stations. Free radios in Germany are therefore at a crossroad. Either they accept substantial state funding and - in the long term - take over functions that have become a nuisance to public service broadcasters, organise volunteer work in the community that helps putting up with the consequences of neo-liberalism without actually fighting it. Or they go back to their roots and activate their social potential. Doing so they could become a junction between social critique and action.

Community radio mostly is both - a poor imitation of mainstream media, who copies its content and a conveyor of alternative content. As I have argued above, what differentiates free radio from other forms of community radio is not so much its alternative content but rather alternative ways of organising its production process. Using conversation analysis I have shown that these alternative ways of organising the production can deeply influence the ways what can be said and who can talk on free radio. The use of the form of news interviews to discuss a topic may give a voice to those who are usually not heard on the mainstream media. 
But at the same time this also implicates the power structure inherent in a news interview, mainly the prerogative of the interviewer to decide the topic, to ask questions and to start and to conclude the interview. But other forms of talk can also be find on free radio programmes, as was shown above. By using what I have called here an orientation towards informal interaction, free radio also has a form of talk at its disposal which tends to involve the listener as supplier. Doing this, it also fulfils its potential described above, namely disenchanting radio as an omniscient medium, participants in events giving their own account of events and the use of ordinary everyday language.

Free radios are pressured today to conform to mainstream media norms - not least due to financial pressure. Therefore, they try to argue that free radio is part of the basic service usually associated with public broadcasting or that they play a vital role in providing training in media literacy. For this reason, so the argument goes, free radios have to be financed by state authorities. But these arguments unsettle the foundations free radio is build upon, first of all its independence from governments and corporate interests. It pressures free radio to produce "good journalism". Free radio started as a form of radical media. Today it can only partially be described as politically radical. But, as I have argued above, it has the potential of being radical media, if it not only transmits alternative content but also organises the listener as producer. It could be different from other media if it realised its potential. Needless to say, quite often free radio stations reproduce hegemonic power structures in their programmes and organisations. But they also make a different form of radio broadcasting possible, one that brings about at least partly equality between all participants producing a programme. The chance that free radio presents is to be a junction where different radical approaches meet. But therefore it must actively promote an emancipatory form of talk and organise listeners as producers and thereby enable processes of communication as opposed to indoctrinating.

\section{Notes}

${ }^{1}$ For a short overview and discussion of these terms see Atton and Couldry (2003) or Vatikiotis (2005).

${ }^{2}$ For the German workers' radio movement of the 1920s and early 1930s see Dahl (1978), for on overview on radios libres in France and Italy see e.g. Lewis and Booth (1989).

${ }^{3}$ For examples see the anthologies edited by Friedmann (1998) and Kupfer/ Thiermann (2005).

${ }^{4}$ While I use one example to present the findings of my research, it is based on all data analysed. The forms of organising talk are recurrently in use on these programmes.

5 The original German transcription of this extract is printed in the appendix. The transcription follows the rules outlined by Sacks/Schegloff/Jefferson (1974). The symbols used here are listed in the appendix. 


\section{References}

Agentur Bilwet (1993) Medien Archiv, Bensheim, Düsseldorf: Bollmann.

Atkinson, J.M. (1982) 'Understanding Formality. The Categorization and Production of "Formal" Interaction', British Journal of Sociology 33 (1): 86117.

Atton, C. and N. Couldry (2003) 'Introduction', Media, Culture \& Society 25 (5): 579586.

Benjamin, W. (1978) 'The Author as Producer', in A. Arato and E. Gebhardt (eds.) The Essential Frankfurt School Reader, New York: Urizen Books, pp. 254-269.

Brecht, B. (1975) 'Der Rundfunk als Kommunikationsapparat', in Gesammelte Werke, Bd. 18, Frankfurt am Main: Suhrkamp, pp. 127-134.

Brecht, B. (1993) 'The Radio as an Apparatus of Communication', in N. Strauss (eds.) Radiotext(e), New York: Semiotext(e), pp. 15-17.

Buchholz, K. (2005) 'Nichtkommerzieller lokaler Hörfunk und Grundversorgung', in T. Kupfer and S. Thiermann (eds.) Von der Kür zur Pflicht? Perspektiven des Nichtkommerziellen Lokalen Hörfunks, Berlin: Vistas, pp. 71-76.

Busch, C. and Freundeskreis Freie Radios Münster (1981) Was Sie schon immer über Freie Radios wissen wollten, aber nie zu fragen wagten!, Frankfurt am Main.

Dahl, P. (1978) Arbeitersender und Volksempfänger. Proletarische Radio-Bewegung und bürgerlicher Rundfunk bis 1945, Frankfurt am Main: Syndikat.

Diefenbach, K. (1998) 'Die Liebe zu den sprechenden Mikromedien. 5- MinutenRadiotheorie der Bewegung', in R. Friedmann (ed.) Kurze Welle - lange Leitung. Texte zur Radioarbeit, Zürich: Shedhalle, pp. 63-79.

Downing, J. (1984) Radical Media. The political experience of alternative communication, Boston: South End Press.

Downing, J. (2001) Radical Media. Rebellious Communication and Social Movements, London: Sage.

Downing, J.D.H. (2003) 'Audiences and Readers of Alternative Media. The Absent Lure of the Virtually Unknown', Media, Culture \& Society 25 (5): 625-645.

Eco, U. and A.J. Grieco (1978) 'Independent Radio in Italy. Cultural and Ideological Diversification', Cultures 5 (1): 122-132.

Enzensberger, H.M. (1970) 'Constituents of a Theory of Media', in J.T. Caldwell (eds.) Electronic Media and Technoculture, New Brunswick: Rutgers University Press, pp. 51-76.

Faecke, P. and G. Haag (1977) 'Wer spricht für wen?', alternative 20 (114/115): 110111.

FRED - Federazione Radio Emittenti Democratiche (1977) 'Thesen zur Theorie und Praxis der demokratischen Sender. Diskussionspapier der FRED zum nationalen Kongreß, Mai ‘77, Rom (Auszüge)', alternative 20 (114/115): 141143.

Friedmann, R. (ed.) (1998) kurze Welle - lange Leitung. Texte zur Radioarbeit, Zürich: Shedhalle. 
Heritage, J. (1985) 'Analyzing News Interviews. Aspects of the Production of Talk for an Overhearing Audience', in T.A. van Dijk (eds.) Handbook of Discourse Analysis, Amsterdam: Academic Press, pp. 95-117.

Heritage, J. and D. Greatbatch (1991) 'On the Institutional Character of Institutional Talk. The Case of News Interviews', in D. Boden and D. H. Zimmerman (eds.) Talk and Social Structure. Studies in Ethnomethodology and Conversation Analysis., Cambridge: Polity, pp. 93-137.

Heritage, J., S. Clayman and D.H. Zimmerman (1988) 'Discourse and Message Analysis. The Micro-Structure of Mass Media Messages', in R.P. Hawkins, J.M. Wiemann and S. Pingree (eds.) Advancing Communication Science. Merging Mass and Interpersonal Processes, Newbury Park: Sage, pp. 77-109.

Kupfer, T. and S. Thiermann (eds.) (2005) Von der Kür zur Pflicht? Perspektiven der Nichtkommerziellen Lokalen Hörfunks (NKL), Berlin: Vistas.

Lewis, P.M. and J. Booth (1989) The Invisible Medium. Public, Commercial and Community Radio, Basingstoke: Macmillan.

Negt, O. and A. Kluge (1993) Public Sphere and Experience. Toward an Analysis of the Bourgeois and Proletarian Public Sphere, Minneapolis: University of Minnesota Press.

Network Medien-Cooperative and Freundeskreis Freie Radios Münster (1983) Frequenzbesetzer. Arbeitsbuch für ein anderes Radio, Reinbek: Rowohlt.

Psathas, G. (1995) Conversation Analysis. The Study of Talk-in-Interaction, Thousand Oaks: Sage.

Ruoff, R. (1978) "...und da haben die Leute gemerkt, daß das Instrument wichtig und interessant ist." $\mathrm{Zu}$ den demokratischen lokalen Radiosendern in Italien', Ästhetik und Kommunikation 9: 5-21.

Sacks, H., E.A. Schegloff and G. Jefferson (1974) 'A Simplest Systematics for the Organization of Turn-Taking for Conversation', Language 50: 696-735.

Stamm, K. (1991) 'Diffusionseffekte der alternativen in die massenmediale Öffentlichkeit', in R. Roth and D. Rucht (eds.) Neue soziale Bewegungen in der Bundesrepublik Deutscbland, Bonn: Bundeszentrale für politische Bildung, pp. 359-378.

Stötzler, M. (1998) 'Der Sonntag des Sprechens', karoshi 2 (1): 4-9.

Vatikiotis, P. (2005) 'Communication Theory and Alternative Media', Westminster Papers in Communication and Culture 2 (1): 1-29.

Vogel, A. (1991) Rundfunk für alle. Bürgerbeteiligung, Partizipation und zugangsoffene Sendeplätze in Hörfunk und Fernsehen, Berlin: Vistas.

Weichler, K. (1987) Die anderen Medien. Theorie und Praxis alternativer Kommunikation, Berlin: Vistas.

Wenzel, U. (1998) 'Produktionsweisen und Rezeptionsweisen. Zum Potential emanzipatorischer Rundfunkästhetik', in R. Friedmann (ed.) Kurze Welle lange Leitung. Texte zur Radioarbeit, Zürich: Shedhalle, pp. 17-39. 


\section{Appendix}

$\begin{array}{ll}\text { Transcription Symbols } & \\ {[\text { ] ] }} & \text { start and end of overlap } \\ = & \text { latching } \\ (.)(-)(--)(---) & \text { very short, short, longer, long pause } \\ ? & \text { strongly rising intonation } \\ , & \text { slightly rising intonation } \\ ; & \text { slightly falling intonation } \\ . & \text { strongly falling intonation } \\ \underline{\text { this }} & \text { accented } \\ \text { it- } & \text { cut-off word }\end{array}$

Transcript in the Original Version

Transcript: coloRadio-Magazin, 10/12/98

Extract: Stadtrat

Elli-presenter, Vera-on the phone

$\begin{array}{lll}01 & \text { Elli: } & \text { [aha; ] } \\ 02 & \text { Vera: } & \text { [und ] muss ne sehr große mehrheit geben. und } \\ 03 & (-) \text { die frau, die de- die jetz gewählt worden } \\ 04 & \text { is, war vorschlag des obs, seine } \\ 05 & \text { wunschkandidatin; hat- war aber nich, eh ich } \\ 06 & \text { sag ma; nich die idealfrau von (.) vielen } \\ 07 & \text { frauen im stadtrat. also es war (-) wir finden } \\ 08 & \text { sie sympathisch; aber es war nich die frau; } \\ 09 & \text { die wir uns fachlich und auch so von der } \\ 10 & \text { zusammenarbeit der frauenprojekte her mit- als } \\ 11 & \text { gleichstellungsbeauftragte gewünscht hätten. } \\ 12 & \text { die frauenprojekte ham ne andere frau (-) } \\ 13 & \text { favorisiert. und eh wir hatten eigentlich } \\ 14 & \text { gehofft, dass wir im stadtrat dann noch mal } \\ 15 & \text { darüber diskutieren können, zumal zwei } \\ 16 & \text { ausschüsse sich damit beschätigt hatten im } \\ 17 & \text { stadtrat, und zu verschiedenen voten (-) } \\ 18 & \text { gekommen sind. die einen- der eine ausschuß } \\ 19 & \text { hat die kandidatin des oberbürgermeisters } \\ 20 & \text { favorisiert, carla schmidt, aus meißen, der } \\ 21 & \text { andere ausschuß hat die- eine andere } \\ 22 & \text { kandidatin favorisiert; doktor berta meier } \\ 23 & \text { aus dresden; die auch eine bündnisgrüne ist. } \\ 24 & \text { (--) aber die diskussion hat=s nicht gegeben; } \\ 25 & \text { und das wurde ganz schnell abgestimmt; und eh } \\ 26 & \text { frau (.) carla schmidt ist neue } \\ 27 & \text { gleichstellungsbeauftragte. } \\ 28 & \text { Elli: } & \text { und wie kam es jetz zu- dass dass genau sie (.) } \\ 29 & \text { in der abstimmung favorisiert wurde? }\end{array}$




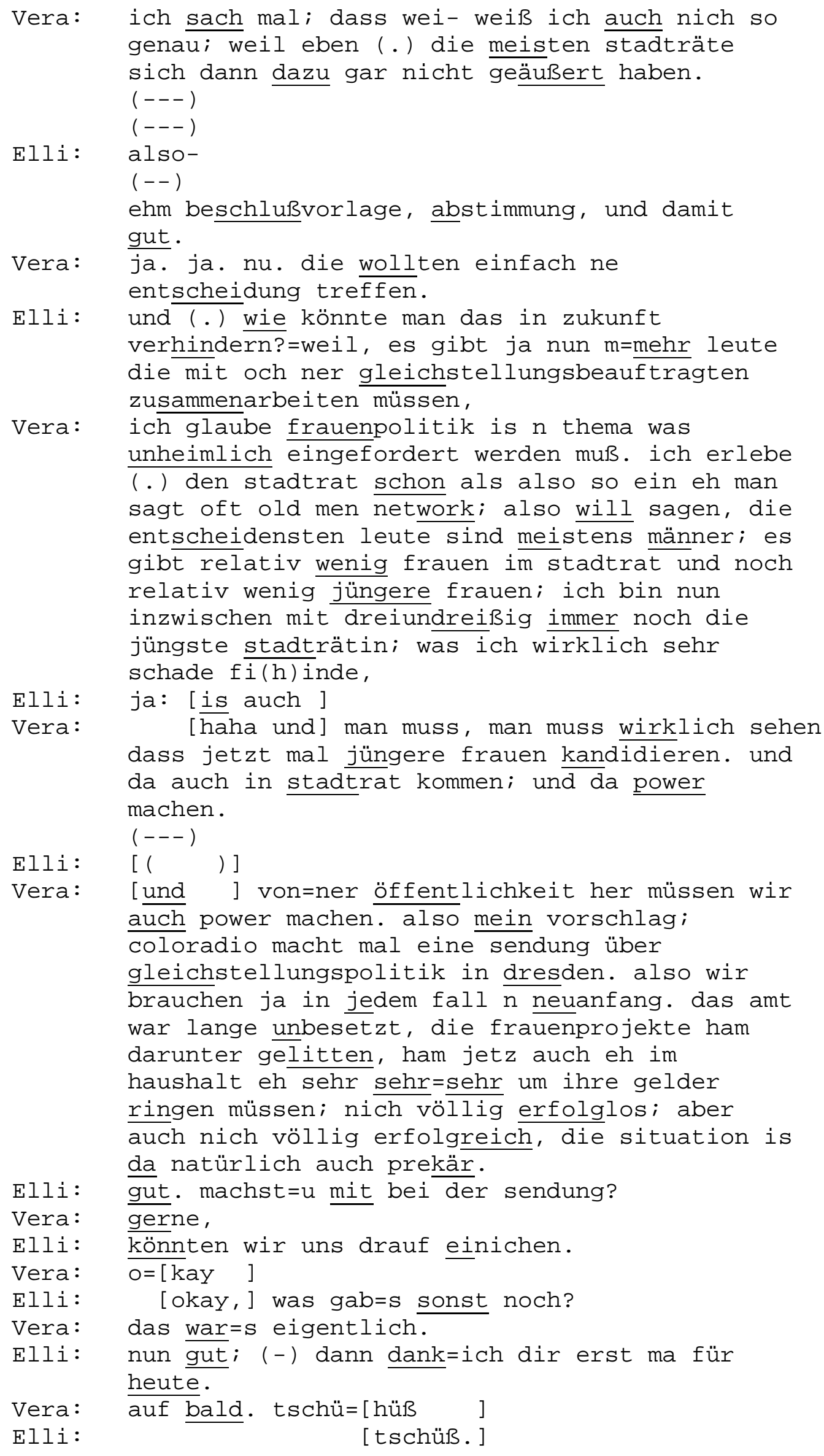

